\title{
Rocky islands in a sea of mud: biotic and abiotic factors structuring deep-sea dropstone communities
}

\author{
Kirstin S. Meyer ${ }^{1, *}$, Craig M. Young ${ }^{1}$, Andrew K. Sweetman ${ }^{2}$, James Taylor ${ }^{3}$, \\ Thomas Soltwedel ${ }^{3}$, Melanie Bergmann ${ }^{3}$ \\ ${ }^{1}$ Oregon Institute of Marine Biology, 63466 Boat Basin Road, Charleston, OR 97420, USA \\ ${ }^{2}$ The Lyell Centre for Earth and Marine Science and Technology, Heriot Watt University, Edinburgh, UK \\ ${ }^{3}$ Alfred-Wegener-Institut Helmholtz-Zentrum für Polar- und Meeresforschung, Am Handelshafen 12, \\ 27570 Bremerhaven, Germany
}

\begin{abstract}
Stones released by melting icebergs are called dropstones, and these stones constitute island-like hard-bottom habitats at high latitudes. In 2012, dropstone megafauna in the HAUSGARTEN observatory in the Fram Strait was sampled photographically. We tested the hypothesis that dropstones would have the same species distribution patterns as terrestrial islands, using 5 patterns commonly found in the classical island literature. Higher richness, diversity, and abundance of fauna occurred on larger stones and on stones near a deep-water rocky reef. These patterns can be explained by the greater surface area of larger stones, the exposure of larger stones to faster current higher in the benthic boundary layer, and increased larval supply from the rocky reef. Some pairs of morphotypes (12 pairs out of 56 morphotypes and 1540 possible pairs) co-occurred less often than expected by chance. While similar patterns have been attributed to interspecific competition in the classical island literature, we offer alternative mechanisms for dropstones. Non-random co-occurrence on dropstones may be explained by larval dispersal. Dropstone fauna had an overdispersed (clumped) distribution, so pairs of morphotypes may have negative non-random co-occurrence simply because short larval life and limited dispersal ability prevent them from having randomly overlapping distributions. In addition, we found 8 morphotype pairs that co-occurred more often than expected by chance because of epibiontism. The patterns found in dropstone communities resemble terrestrial islands, but different mechanisms may be responsible.
\end{abstract}

KEY WORDS: Assembly rules $\cdot$ Island biogeography $\cdot$ HAUSGARTEN $\cdot$ Megafauna $\cdot$ Encrusting fauna $\cdot$ Hard substrata

\section{INTRODUCTION}

Island fauna have been of interest to ecologists for many years because of the unique characteristics they possess: the contradictory phenomena of nanism and gigantism, and low species richness countered by high endemicity (Whittaker \& Fernandez-Palacios 2007). The fauna and flora in island-like habitats have filled a substantial body of ecological literature because an understanding of isolated habitats in- forms such wide-ranging problems as dispersal, succession, and the design of natural reserves (Tjørve 2010).

Even though much of the island ecology literature centers on terrestrial habitats, the deep sea contains numerous isolated hard-bottom habitats (Young 2009) with high biodiversity that may function like islands. Island-like habitats at the deep seafloor range in size from landscape-scale features such as seamounts (Clark et al. 2010) and canyons (De Leo et al. 2010) to 
isolated chemosynthetic communities at hydrothermal vents (Lutz \& Kennish 1993), cold seeps (Sibuet \& Olu 1998), sunken wood (Bienhold et al. 2013), and whale falls (Smith \& Baco 2003) and to small-scale structures such as manganese nodules (Mullineaux 1987), sea urchin tests (Hétérier et al. 2008), and sponge stalks (Beaulieu 2001).

In this study, we focus on the isolated hard-bottom communities on dropstones in the Fram Strait, between Greenland and Svalbard. The Fram Strait is the only deep-water connection between the North Atlantic and the central Arctic and is seasonally icecovered (Soltwedel et al. 2005), so it provides a good study area for Arctic deep-sea ecology in a relatively accessible environment. Dropstones are stones, here defined as anything larger than a pebble $(>6.4 \mathrm{~cm}$; Wentworth 1922), that become frozen in glaciers, then are carried out to sea and released by melting icebergs. Dropstones constitute the most common hard substrata north of $45^{\circ} \mathrm{N}$ in the North Atlantic (Kidd et al. 1981). They are inhabited primarily by sessile, suspension-feeding invertebrates (Oschmann 1990, Schulz et al. 2010) and can serve as a 'resting place' for motile fauna such as shrimps and amphipods. Dropstones increase habitat heterogeneity and megafaunal diversity where they occur (MacDonald et al. 2010). The presence of a dropstone can also lead to higher functional diversity of the surrounding meiofauna (Hasemann et al. 2013). Dropstones, like most other hard substrata in the deep sea (Young 2009), are essentially hard-substratum islands surrounded by a sea of mud.

Using image analysis, we quantify the biotic and abiotic factors that may structure dropstone communities. Classical island theory (including MacArthur \& Wilson's [1967] equilibrium theory of island biogeography and Diamond's [1975] assembly rules) have pointed to the influences of island size (Connor \& McCoy 1979), proximity to a mainland (MacArthur \& Wilson 1967), and interspecific competition (Diamond 1975) on insular fauna. Each of these classical theories has been criticized and modified since first publication (Connor \& Simberloff 1979, Anderson \& Wait 2001), filling a large body of literature even in recent years (Lomolino 2000, Gotelli 2001, Whittaker et al. 2008, Borregaard et al. 2016). In this analysis, we examine the effects of these classical factors on dropstone communities: size, proximity to a potential source population, and biotic interactions among the fauna. Biotic interactions indicated by the position of organisms (overgrowth competition and epibiontism) can be directly observed using image analysis.
Five species distribution patterns are commonly found on terrestrial islands: (1) a log-linear relationship between species richness and island size, (2) 'incidence functions,' or different community composition on islands of different size, (3) higher species richness on islands located closer to a mainland source population, (4) nestedness, or ever-smaller or ever-more-isolated habitats being inhabited by eversmaller sub-sets of species, such that each sub-set is nested within the next-largest faunal sub-set, and (5) non-random co-occurrence, or pairs of species being found together less often (negative non-random cooccurrence) or more often (positive non-random cooccurrence) than expected by chance.

In this study, we apply these 5 species distribution analyses to dropstone communities, in each case testing the hypothesis that dropstone communities have the same species distribution patterns as terrestrial islands. We compare our results to patterns found in terrestrial island communities and discuss how our findings may enlighten current thought on other island-like habitats.

\section{MATERIALS AND METHODS}

\section{Image collection}

Images of the seafloor were recorded in July 2012, during expedition ARK XXVII/2 of German research icebreaker RV 'Polarstern', from 5 stations in the long-term ecological research (LTER) observatory HAUSGARTEN, in the eastern Fram Strait (Soltwedel et al. 2005). Bottom temperature in the study area is $\sim-0.8^{\circ} \mathrm{C}$, and bottom current speed is $\sim 5 \mathrm{~cm}$ $\mathrm{s}^{-1}$ to the northwest (Meyer et al. 2014, Soltwedel et al. 2016). Four of the 5 stations (S3, HG IV, N3, and N5) analyzed represent soft-sediment sites and constitute a latitudinal transect along the $2500 \mathrm{~m}$ isobath, while the remaining station, here referred to as 'Senke,' includes a steep deep-water rocky reef (Table 1, Fig. 1). However, at the Senke site, photographs included in the present image analysis were all recorded from the soft-sediment seafloor at the foot of the reef (Meyer et al. 2014). The Senke rocky reef is the only rocky reef known in the HAUSGARTEN area, as the majority of the seafloor is composed of soft sediments (Soltwedel et al. 2005). Dropstone densities along the latitudinal transect (S3, HG IV, and N3) are not significantly different, but there are more pebbles (i.e. stones $\leq 6.4 \mathrm{~cm}$ diameter) at the northerly stations, corresponding to increased ice cover (Taylor et al. 2016). 
Table 1. Summary of Ocean Floor Observation System (OFOS) deployments during ARK XXVII/2

\begin{tabular}{|c|c|c|c|c|c|c|c|c|}
\hline $\begin{array}{l}\text { Photographic } \\
\text { transect no. }\end{array}$ & Stn & Date & $\begin{array}{l}\text { Start latitude } \\
(\mathrm{N})\end{array}$ & $\begin{array}{l}\text { Start longitude } \\
\text { (E) }\end{array}$ & $\begin{array}{l}\text { Start depth } \\
(\mathrm{m})\end{array}$ & $\begin{array}{l}\text { End latitude } \\
(\mathrm{N})\end{array}$ & $\begin{array}{l}\text { End longitude } \\
\qquad(\mathrm{E})\end{array}$ & $\begin{array}{l}\text { End depth } \\
\text { (m) }\end{array}$ \\
\hline PS80/176-1 & S3 & 19-Jul-2012 & $78^{\circ} 37.04^{\prime}$ & $5^{\circ} 00.07^{\prime}$ & 2360 & $78^{\circ} 37.00^{\prime}$ & $5^{\circ} 8.56^{\prime}$ & 2352 \\
\hline PS80/179-3 & HG IV & 21-Jul-2012 & $79^{\circ} 01.98^{\prime}$ & $4^{\circ} 09.75^{\prime}$ & 2630 & $79^{\circ} 03.88^{\prime}$ & $4^{\circ} 17.18^{\prime}$ & 2409 \\
\hline PS80/186-5 & N5 & 24-Jul-2012 & $79^{\circ} 56.07^{\prime}$ & $3^{\circ} 07.98^{\prime}$ & 2534 & $79^{\circ} 55.63^{\prime}$ & $3^{\circ} 05.69^{\prime}$ & 2554 \\
\hline PS80/193-1 & N3 & 26-Jul-2012 & $79^{\circ} 36.04^{\prime}$ & $5^{\circ} 09.88^{\prime}$ & 2748 & $79^{\circ} 33.53^{\prime}$ & $5^{\circ} 16.99^{\prime}$ & 2608 \\
\hline PS80/196-1 & Senke & 27-Jul-2012 & $79^{\circ} 05.98^{\prime}$ & $4^{\circ} 23.01^{\prime}$ & 2296 & $79^{\circ} 06.02^{\prime}$ & $4^{\circ} 33.92^{\prime}$ & 2041 \\
\hline
\end{tabular}

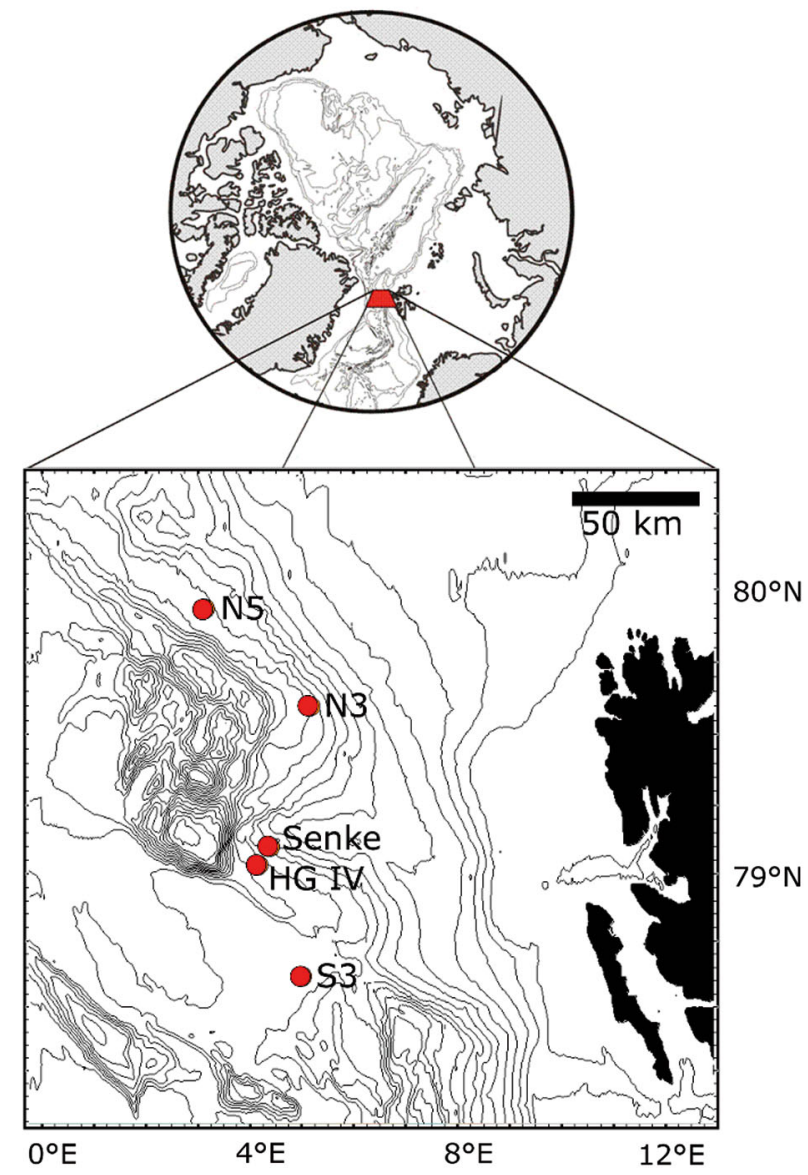

Fig. 1. Stations in the HAUSGARTEN observatory where dropstone images were recorded. Depth contours are shown every $250 \mathrm{~m}$

Images were recorded using a downward-facing towed camera system, the Ocean Floor Observation System (OFOS), and specifics are reported by Meyer et al. (2013) for 2012 sampling. The target altitude was $1.5 \mathrm{~m}$, and each image shows approximately 3 to $4 \mathrm{~m}^{2}$ of the seafloor. Three lasers were each mounted $52 \mathrm{~cm}$ apart on the camera frame to produce points in the photos that were used for size reference. Images were recorded automatically every $30 \mathrm{~s}(\sim 7$ to $8 \mathrm{~m}$ apart), and additional manually triggered images were recorded when objects of interest were observed. Each image was geo-referenced with a unique latitude and longitude.

\section{Image analysis}

Images that were unusually bright, unusually dark or outside the most common range of altitudes (1.3 to $1.6 \mathrm{~m}$ above the seafloor) were considered ineligible for analysis. To calculate the density of dropstones at each station in 2012, 40 automatically recorded images (which did not necessarily contain dropstones) were randomly sub-selected (using a random number generator) from the eligible images at each station, and the number of stones in each image was counted and divided by the image area to give stones $\mathrm{m}^{-2}$. To assess the change in dropstones and pebble densities over time, 80 images per year were randomly selected from eligible archived OFOS images recorded at Stns N3 and S3 in summer, 2011 to 2015 (Taylor et al. 2016).

For the analysis of dropstone fauna, 40 automatically recorded eligible images showing stones of any size were randomly sub-selected for each station. Stones were clearly discernable in the images and not easily confused with biogenic substrata. Stones observed in the automatic images were primarily of small size (cobbles, 6.4 to $25.6 \mathrm{~cm}$; Wentworth 1922) for every station except Senke; therefore, an additional 40 manually triggered images containing boulders $(>25.6 \mathrm{~cm}$, large enough to be seen without zooming in on the image) were also randomly sub-selected from the eligible images for Stns S3, HG IV, N3, and N5 (the first set of images from Senke already had many boulders). This procedure was used so that the full size range of dropstones would be represented in the dataset. Images containing large stones also featured many small stones, and every stone in the images was counted. Only 61 images containing dropstones were available from Stn N5, so 541 images and 1677 individual stones were analyzed altogether. 
The plan area of each stone was traced using the freehand selection tool and measured in ImageJ (NIH). Megafauna present on each stone were counted and sorted into morphotypes. Some morphotypes could be identified by comparison to the results of Bergmann et al. (2011). For those morphotypes also observed on the rocky reef at station Senke, morphotype names in this study match the names used by Meyer et al. (2014).

\section{Data analysis}

To determine whether dropstones were randomly distributed on the seafloor, we tested if the frequency distribution of stone densities differed significantly from a Poisson distribution using a G-test in Biomstat v4 (Exeter Software, USA). A G-test was also used to determine if dropstone fauna were randomly distributed among stones by comparing to a Poisson distribution. Changes in dropstone density over time were tested with ANOVA, using Levene's test to establish homoscedasticity. Logarithmic best-fit curves of the abundance, richness, evenness, and diversity of fauna against stone size and non-parametric correlations of these biotic indices against distance to the Senke rocky reef were constructed using Biomstat. The variables 'morphotype richness' and 'stone area' were each log-transformed to see whether dropstone communities showed the classical log-linear relationship between these variables (Connor \& McCoy 1979). Correlations between the biotic community composition and other dropstone parameters (stone size, location, and distance to the Senke rocky reef) were sought using Mantel tests in R (Paradis et al. 2004, R Development Core Team 2013).

To test for significantly nested patterns of the megafauna, we used the $\mathrm{N}_{1}$ and $\mathrm{BR}$ indices in the software Nestedness (Ulrich 2006) according to the recommendation of Ulrich \& Gotelli (2007) and a fixed-fixed null model to generate $95 \%$ confidence intervals of each index. Non-random patterns of species co-occurrence were sought for each station using the software EcoSim (Entsminger 2014). According to the recommendation of Gotelli (2000) for archipelago-like datasets, we used a fixed-fixed null model and the $C$ score index. To detect pairwise non-random co-occurrence patterns of species, we used the software Pairs (Ulrich 2008), once again applying the $C$-score index of co-occurrence and a fixed-fixed null model. Bayes $M$ crite- rion was used to assess the significance of pairwise comparisons, following Gotelli \& Ulrich (2010).

\section{RESULTS}

\section{Dropstones as habitats}

Dropstones had a clumped distribution on the seafloor. The frequency distribution of dropstone densities was skewed right and differed significantly from a Poisson distribution (G-test, $G=326$, p $<0.001$; Fig. 2), with a variance-to-mean ratio of 8.3. However, a test for spatial auto-correlation of stone density against distance to the Senke rocky reef indicated a significant negative correlation (Mantel test based on Euclidean distance matrices, $z=2.6 \times 10^{8}$, $\mathrm{p}=0.001$ ), meaning that images the same distance from the Senke rocky reef had significantly dissimilar stone densities. In other words, clusters of stones were distributed on the seafloor without regard for distance from the rocky reef. Distance to the reef could thus be considered as an independent variable potentially influencing dropstone communities.

Dropstones and pebbles each had significantly higher density at Stn S3 in 2015 than in 2011 to 2013 (dropstones, ANOVA, $F=3.39, \mathrm{p}=0.018$; pebbles, ANOVA, $F=202.65$, p < 0.001; Fig. 3). At Stn N3, the density of dropstones was not significantly different among years (ANOVA, p > 0.05), but pebbles had higher density in later years (2013-2015) than in 2011 to 2012 (ANOVA, $F=42.77$, p < 0.001; Fig. 3).

Dropstone size was not significantly spatially autocorrelated (Mantel test using Euclidean distance matrices based on stone size and latitude/longitude,

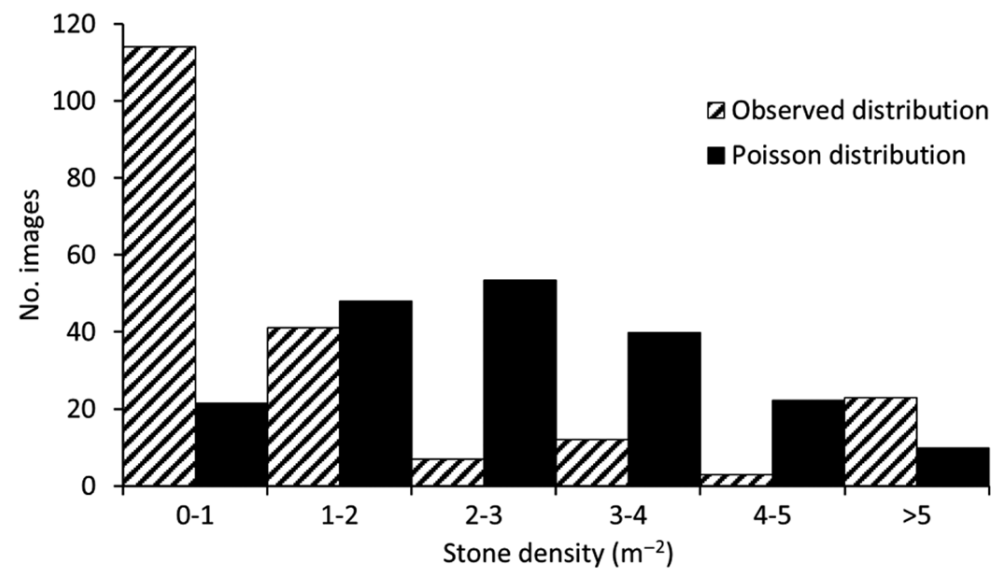

Fig. 2. Frequency distribution of dropstone densities in 40 randomly sub-selected images from each station, and a Poisson distribution with the same mean. A significant difference between the 2 distributions (see text) indicates a clumped distribution of dropstones in the study area 

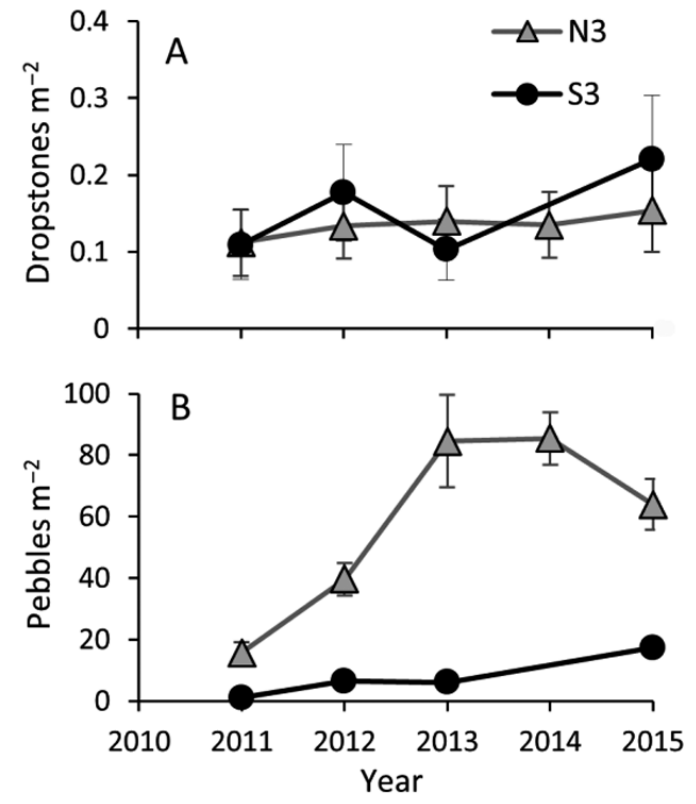

Fig. 3. Density $\left(\mathrm{m}^{-2}\right)$ of $(\mathrm{A})$ dropstones and (B) pebbles at Stns N3 and S3 in the HAUSGARTEN observatory, 2011-2015. Error bars show 95 \% confidence intervals; error bars for pebbles at S3 are small enough to not be visible. Note different $y$-axis scales photype diversity. The number of individuals (N), species richness $(S)$, Margalef richness $(d)$, evenness $\left(J^{\prime}\right)$, and Shannon-Wiener diversity $\left(H^{\prime}\right)$ of the fauna on a particular stone all showed a logarithmic relationship to the stone size (Fig. 5A-E). The relationship was strongest for $H^{\prime}\left(\mathrm{R}^{2}=0.57\right)$ and $S\left(\mathrm{R}^{2}=0.53\right)$ and weakest for $N\left(R^{2}=0.38\right)$. A log-log transformation of the species-area plot is commonly reported for terrestrial islands (MacArthur \& Wilson 1967, Rusterholz \& Howe 1979), and a similar transformation of the dropstone data also revealed a log-log relationship of species richness and stone area $\left(\mathrm{R}^{2}=0.52\right.$; Fig. 5F). Hypothesis 1 (see 'Introduction') was thus supported.

Despite the higher diversity observed on larger stones, there was not a significant correlation between the composition of the biotic community (represented in a Bray-Curtis similarity matrix) and the size of the stone (Euclidean distance matrix) (Mantel test, $z=8.8 \times 10^{8}, p=0.469$ ). In other words, stones of the same size did not necessarily have similar faunal composition. This result means there was no evidence of 'incidence functions' (Hypothesis 2) for dropstone communities.

$\left.z=7.6 \times 10^{7}, p=0.243\right)$ and was also not significantly correlated to distance from the Senke rocky reef (Mantel text using Euclidean distance matrices, $z=$ $3.8 \times 10^{9}, \mathrm{p}=0.963$ ). Therefore, the size of a dropstone is not related to its position on the seafloor, so stone size can be considered as an independent factor potentially influencing the biotic communities.

About $71 \%$ of all dropstones were inhabited by at least 1 individual. Most of the morphotypes found on dropstones were sponges or cnidarians, and about $96 \%$ of dropstone fauna were suspension feeders (see Table S1 in the Supplement at www.int-res.com/articles/ suppl/m556p045_supp.pdf). Examples of dropstone communities from each station are shown in Fig. 4, and morphotypes found on dropstones are depicted in Figs. S1 to S7 in the Supplement.

\section{Relationship of stone size to the biotic community}

Larger dropstones were inhabited by more individuals and had higher mor-

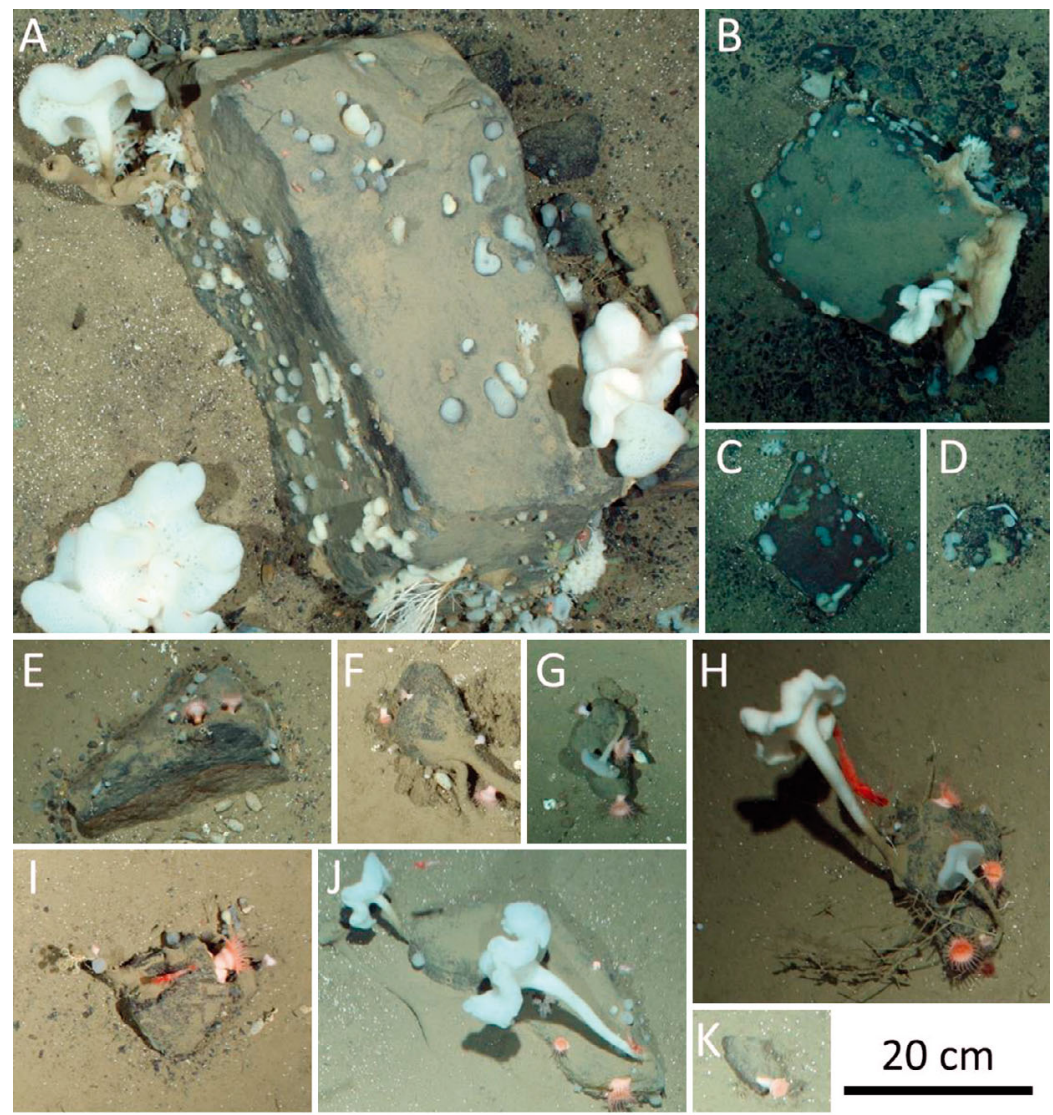

Fig. 4. Examples of dropstone communities on stones of varying size and at different stations. (A-D) Senke; (E-G) HG IV; (H) N5; (I) N3; (J-K) S3 


\section{Relationship of dropstone distribution to the biotic community}

Dropstone fauna had an overdispersed (clumped) distribution. The frequency distribution of $\mathrm{N}$ (number of individuals on a stone) differed significantly from a Poisson distribution ( $G$-test, $G=1.5 \times 10^{4}, \mathrm{p}<0.001$; Fig. 6), with a variance-to-mean ratio of 87.8. This was the case for every morphotype (heterogeneity $G=0$, $\mathrm{p}=1$ ). A significant spatial auto-correlation was found for dropstone faunal composition (Mantel test using Bray-Curtis similarity matrix based on the biotic data and Euclidean distance matrix based on latitude/longitude, $z=4.3 \times 10^{6}, \mathrm{p}=0.001$ ), meaning that stones closer to one another in space had more similar biotic communities. Even when a presence-absence transformation of the biotic data was used, a significant spatial auto-correlation was found (Mantel test, $z=5.5$ $\times 10^{6}, \mathrm{p}=0.001$ ), which means that differences in the biotic communities in different parts of the study area were due to the presence or absence of morphotypes and not just their relative abundances.

The greatest richness, abundance, evenness, and diversity of dropstone fauna was found at Stn Senke, located at the foot of the rocky reef. A range of values was found at each station, though greater maximum values for richness, abundance, and diversity were found at stations closer to the reef.
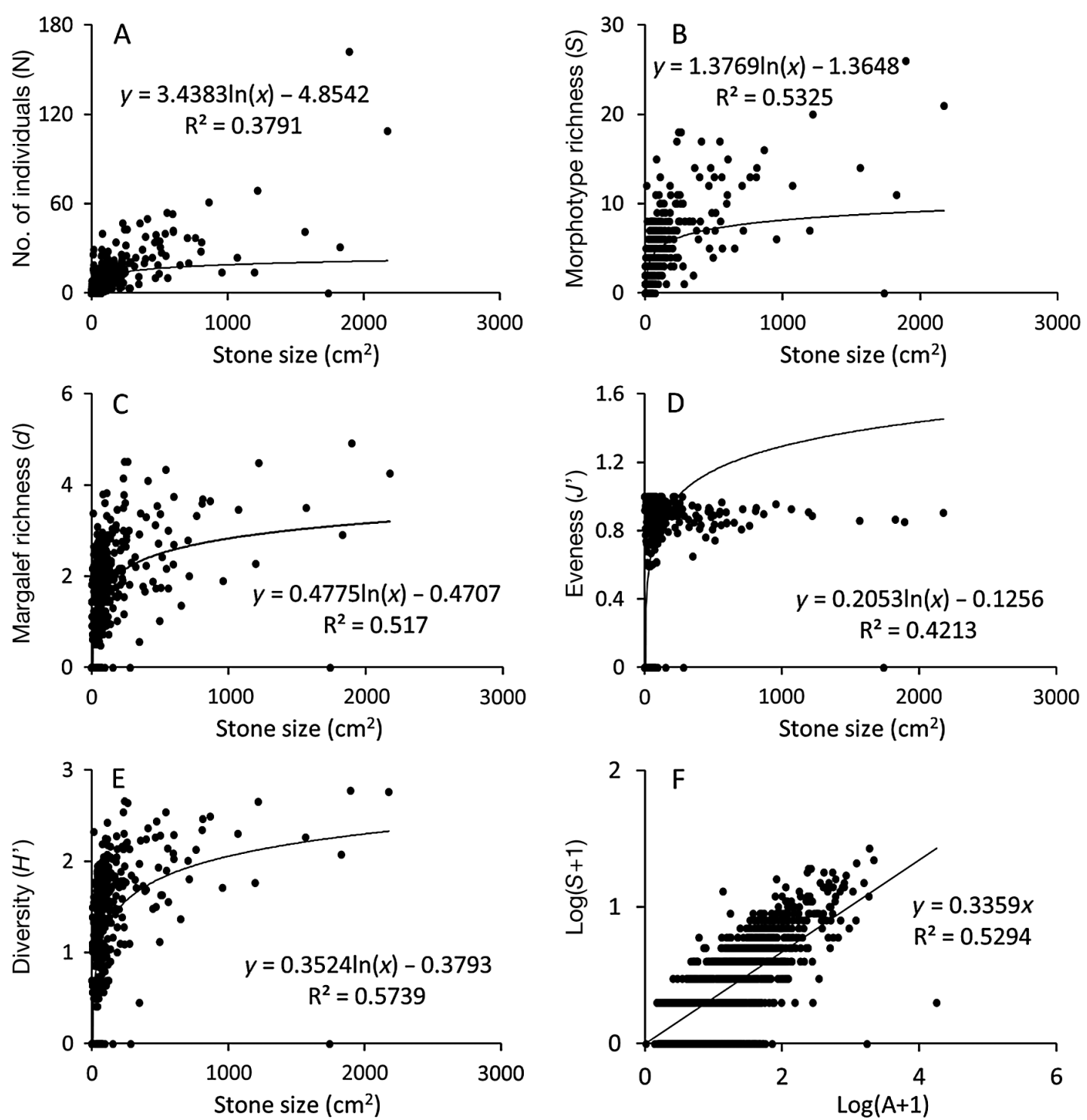

Fig. 5. (A-E) biotic parameters (abundance, richness, evenness, and diversity of fauna) on a dropstone versus the size (surface area visible in downward-facing view); (F) morphotype richness on a dropstone versus the size of the stone, with each axis $\log (x+1)$-transformed to show the log-linear species-area relationship common among island systems in the classical literature 


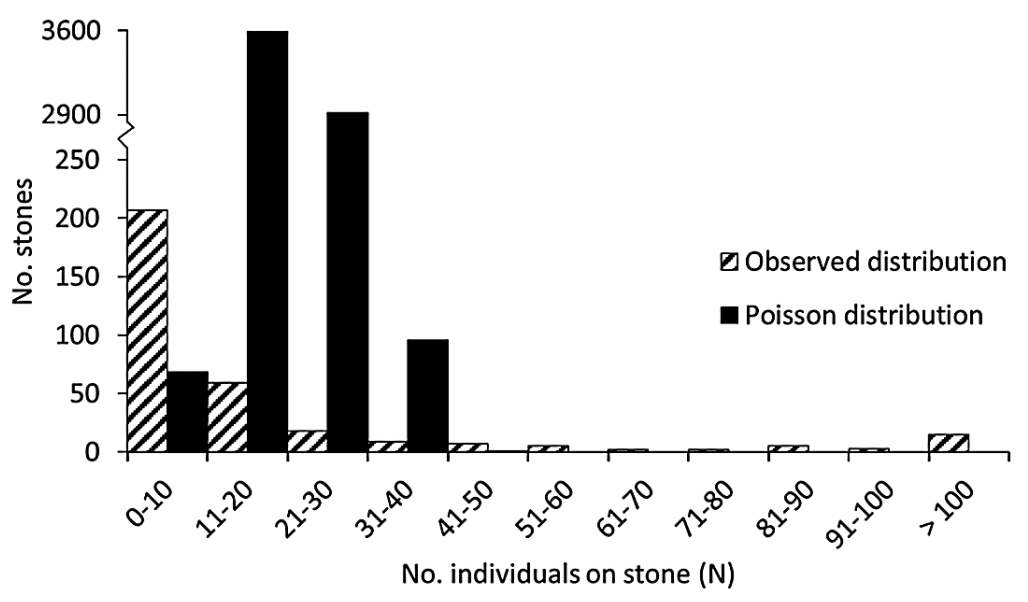

Fig. 6. Frequency distribution of the number of individuals on a dropstone $(\mathrm{N})$, and a Poisson distribution with the same mean. A significant difference between the 2 distributions (see text) indicates that dropstone fauna have a clumped distribution

Abundance, richness, evenness, and diversity each showed a significant negative correlation to distance from the rocky reef (Fig. 7). Hypothesis 3 was thus supported.

Dropstone fauna showed no evidence of a nested distribution among stations. The $\mathrm{N}_{1}$ (52) and BR (32) indices both fell within the $95 \%$ confidence interval ranges (39-53 and 32-38, respectively). Therefore, Hypothesis 4 was not supported. more often than expected by random chance (Table 2).

\section{DISCUSSION}

\section{Dropstones as habitats}

The clumped distribution of dropstones probably reflects their origin in icebergs. A single iceberg may have carried many stones, which were released at the same time as the iceberg melted. Some stones may have broken off from the rocky reef and rolled down the adjacent slope (Meyer et al. 2014); however, this does not appear to be the primary process affecting the distribution of dropstones because clusters of stones were distributed randomly on the seafloor, without regard for distance to the rocky reef.

Dropstone communities had many of the same species distribution patterns as terrestrial islands. However, the mechanisms driving these patterns may not be the same as those suggested for classical islands or habitat islands. The possible mechanisms structuring dropstone communities are discussed in more detail below.

\section{Interactions between morphotypes}

The data revealed patterns of non-random co-occurrence at 3 of the 5 stations: Senke, HG IV, and N3 ( $\mathrm{C}>\mathrm{e}, \mathrm{p}<0.001)$. Only random co-occurrence patterns were found for Stns N5 and S3 ( $p=0.12$ and 0.09, respectively). Hypothesis 5 was thus partially supported.

Pairwise tests showed only a small number of non-randomly co-occurring morphotype pairs at each station (Table 2). A total of 12 morphotype pairs (of 1540 possible pairs) at 4 stations were found to co-occur less often than expected by random chance. An additional 8 pairs of morphotypes at 3 stations non-randomly co-occurred
Table 2. Morphotype pairs at each station that co-occur more or less often than expected by random chance

\begin{tabular}{|llll|}
\hline Stn & Morphotype 1 & Morphotype 2 & $\begin{array}{c}\text { Less or more often } \\
\text { than by chance? }\end{array}$ \\
\hline S3 & Gray encrusting sponge 1 & Myxillinid sponge & Less \\
S3 & Gray encrusting sponge 1 & Puffy white encrustment & Less \\
S3 & Bathyphellia margaritacea & Gray dome sponge & Less \\
S3 & Bathyphellia margaritacea & Myxillinid sponge & Less \\
S3 & Hormathiidae & Bythocaris cf. leucopis & More \\
S3 & Hormathiidae & Cladorhiza cf. gelida & More \\
S3 & Lobe-like sponge & Pycnogonid & More \\
HG IV & Bathyphellia margaritacea & Poliometra prolixa & Less \\
HG IV & Bathyphellia margaritacea & Lobe-like sponge & Less \\
HG IV & Bathyphellia margaritacea & Gersemia fruticosa & Less \\
HG IV & Polymastia sp. & Thin white encrustment & More \\
HG IV & Poliometra prolixa & Bythocaris cf. leucopis & More \\
HG IV & Poliometra prolixa & Amphipod & More \\
Senke & Yellow encrusting sponge & Phakellia sp. & Less \\
Senke & Asymmetrical white sponge & Gray encrusting sponge 1 & Less \\
N5 & Myxillinid sponge & Gray encrusting sponge 1 & Less \\
N5 & Bathyphellia margaritacea & Myxillinid sponge & Less \\
N5 & Gray encrusting sponge 1 & Puffy white encrustment & Less \\
N5 & Hormathiidae & Bythocaris cf. leucopis & More \\
N5 & Hormathiidae & Cladorhiza cf. gelida & More \\
\hline
\end{tabular}



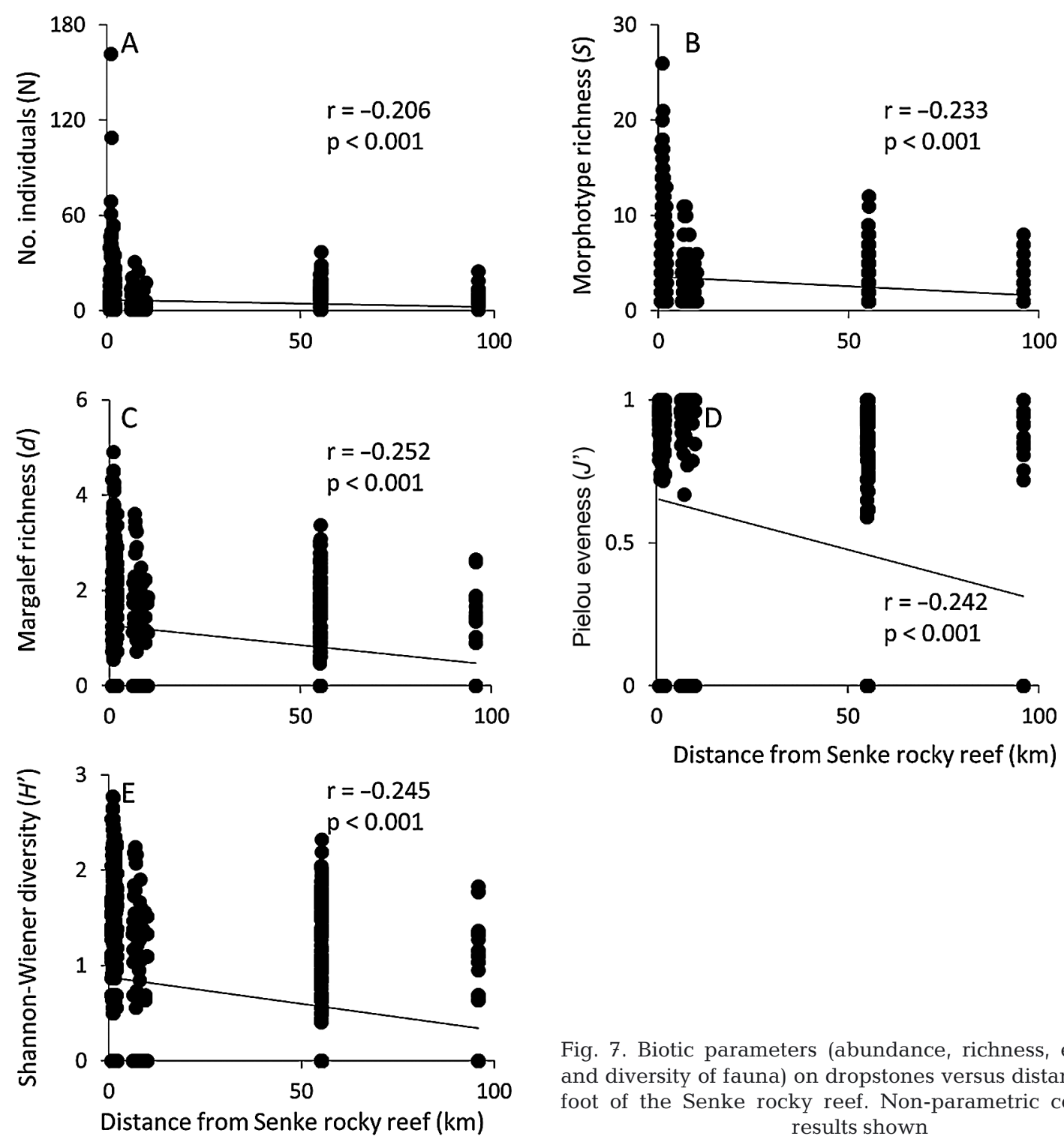

Fig. 7. Biotic parameters (abundance, richness, evenness, and diversity of fauna) on dropstones versus distance to the foot of the Senke rocky reef. Non-parametric correlation results shown

\section{Relationship of stone size to the biotic community}

Our results showed higher species richness on larger stones. Dropstone fauna may thrive on larger stones because of elevated food supply. Larger stones extend higher in the benthic boundary layer, where they are exposed to faster currents that bring particulate food for suspension feeding (Vogel 1996). Suspension feeders are well-known to inhabit elevated substrata on seamounts (Clark et al. 2010) and fjord sills (Mortensen et al. 2001), and on a smaller scale, suspension-feeding foraminifera inhabit glass sponge stalks (Beaulieu 2001) and manganese nodules (Mullineaux 1988). Dropstone megafauna may gain an advantage for suspension feeding by inhabiting larger stones (Schulz et al. 2010).

Larger dropstones may be older, because they would take longer to be covered by sedimentation, and harbor communities at a more advanced stage of succession. However, new dropstones are still being deposited in the study area. Glaciers in west Svalbard fjords have been known to calve icebergs carrying terrestrial material in modern times (Hagen et al. 2003), and ice is also advected into the Fram Strait from the Laptev and Kara seas (M. Bergmann unpubl. data). Our data show a significantly higher density of dropstones at Stn S3 in 2015 (Fig. 3). Both dropstone and hard substratum density also increased significantly at HG IV between 2002 and 2011 (M. Bergmann unpubl data).

On terrestrial islands, habitat diversity, disturbance level, and primary productivity are all correlated 
with island size and have been put forth as explanations for the greater richness of fauna on larger islands (Gotelli \& Graves 1996). However, these factors probably have less of an effect on island-like marine substrata (Abele \& Patton 1976, Schoener \& Schoener 1981). Dropstones are simple habitats; primary production does not occur at the depth of the dropstones, and physical disturbance is relatively rare (though predators, i.e. Hymenaster pellucidus and Lycodes frigidus, may be a source of disturbance on dropstones). In shallow water, larger stones have higher diversity because they are less subject to disturbance by waves (Sousa 1979, Kukliński 2009). However, with a bottom current of approximately $5 \mathrm{~cm} \mathrm{~s}^{-1}$ in the study area, dropstones are very unlikely to be overturned. The higher diversity on larger dropstones must thus be the result of another mechanism.

Based on our data, the most parsimonious explanation for the higher richness and abundance of fauna on larger stones is the 'passive sampling' hypothesis (Gotelli \& Graves 1996). This hypothesis states that larger islands (stones) are colonized by more organisms simply because they are larger targets for dispersing propagules. Larger substrata have more surface area and can accumulate more species in that area as succession proceeds (Schoener \& Schoener 1981). Larger stones are also exposed to faster bottom currents, where the larval flux is probably greater. A greater variety of microhabitats with different flow velocities and shear stresses may be available on larger stones. It would be desirable to separate the effects of habitat heterogeneity and boundary layer current regimes on dropstones experimentally, to understand how these mechanisms structure dropstone communities.

There was no significant correlation between the size of dropstones and the composition of the biotic communities inhabiting them. This means that there is not one set of organisms inhabiting smaller stones (such as opportunists on intertidal boulders) and a separate community inhabiting larger stones. These 'incidence functions' were first suggested by Diamond (1975) for avifauna on terrestrial islands. Instead, the morphotypes present on each stone are a random sub-set of the available morphotypes, and the fauna on larger stones happen to be more diverse because they are a larger sub-set of the available fauna.

Logic dictates that a sufficiently large stone should host the majority or even all of the available morphotypes, and the communities would begin to converge, showing greater similarity at larger stone sizes. How- ever, this is not observed to be the case for dropstone communities, as there was no correlation between stone size and biotic community composition. It is possible that the stones in the present study are simply not large enough to host all available morphotypes of fauna; the maximum morphotype richness on a single stone was 26 , less than half of the 56 available morphotypes found on all dropstones. In contrast, 45 hard-bottom morphotypes inhabit the Senke rocky reef (Meyer et al. 2014).

\section{Relationship of dropstone distribution to the biotic community}

Dropstone fauna were spatially auto-correlated and had a clumped distribution, which may be a result of dispersal via a planktonic larval stage. Many clonal marine hard-bottom species have restricted dispersal $(<1 \mathrm{~km})$, which may be an evolutionarily stable strategy to ensure competent larvae find a suitable substratum for recruitment (Jackson 1986, Grantham et al. 2003, Shanks et al. 2003). At a bottom current speed of $5 \mathrm{~cm} \mathrm{~s}^{-1}$, a larva in the water column for $1 \mathrm{~d}$ in our study area would travel $4.32 \mathrm{~km}$, if its path of motion were linear. However, dropstones cause turbulent eddies on the seafloor (Hasemann et al. 2013), so a larva released from a dropstone is unlikely to have a linear path of motion, and its net distance traveled may be much less.

The rocky reef could serve as a source population for hard-bottom fauna on dropstones, given its dense populations of sessile fauna and its upstream location from 4 of the 5 dropstone stations in this study (Meyer et al. 2014). It appears that increased larval supply from the rocky reef may affect dropstone communities, based on the greater abundance, richness, and diversity of fauna found on stones nearer to the reef (Fig. 7). However, we cannot conclude that the rocky reef is the sole or even the primary source of larvae to the dropstones. If this were the case, one would also expect a nested pattern of the fauna, with more morphotypes present near the reef (at Stn Senke) and nested sub-sets of the fauna present at stations further away. However, our data showed no evidence of nestedness among stations.

In some cases, hard-bottom fauna dispersing to widely spaced substrata may have to delay metamorphosis (Marshall \& Keough 2003), which may affect colony growth or recruits' performance as adults (Marshall \& Keough 2004). However, we have no reason to believe that dropstone fauna would be incapable of reproducing and therefore reliant on the 
rocky reef as a larval source. It is more likely that larvae disperse from both colonized dropstones and the reef, resulting in the patterns observed in our data: clumped distribution of dropstone fauna, and greater abundance, richness, and diversity of fauna closer to the rocky reef.

\section{Interactions between morphotypes}

Morphotypes co-occurred non-randomly at 3 of 5 stations. For those pairs co-occurring less often than expected by random chance, it cannot necessarily be concluded that competitive exclusion is the cause, as is traditionally concluded for terrestrial islands (Diamond 1975). Nine of the 12 morphotype pairs found to have negative non-random co-occurrence included at least one encrusting form. If these encrusting morphotypes were competing, we would expect them to occupy larger portions of the dropstone surface area and even overgrow each other, such as is commonly observed for competing encrusting species in shallow water environments (Sebens 1986, Oschmann 1990). Large portions of the available space on dropstones were in fact left uncolonized (K. S. Meyer unpubl. data, Oschmann 1990). While it is possible that already established fauna on a stone may consume larvae of potentially settling species, experimental evidence from shallow water has shown larval predation does not significantly affect recruitment (Young \& Gotelli 1988, Young 1989, Young \& Cameron 1989).

Rather than competitive exclusion, pairs of morphotypes may non-randomly co-occur on dropstones as a result of their own clumped distributions. If 2 species occur in different parts of the study area or are most abundant in different parts of a particular station, they would seldom be found together.

We also found that 8 morphotype pairs co-occurred more often than expected by random chance. For example, 'Hormathiidae' (Fig. S4B) and Cladorhiza cf. gelida (Fig. S1I) had positive non-random cooccurrence at Stns S3 and N5. Large, erect species such as C. cf. gelida and Caulophacus arcticus (Fig. S1B) were commonly observed being surrounded by mobile crustaceans, including Bythocaris cf. leucopis (Fig. S5A) and 'amphipod' (Fig. S5E). Individuals of C. cf. gelida also in many cases had $\geq 1$ anemones, 'Hormathiidae,' living on them (Fig. 8). Epibionts may be outcompeted on primary substrata and thus be forced to occupy secondary biogenic substrata; basibionts may also increase habitat heterogeneity on dropstones they inhabit. We also find it likely that these epibiotic species take advantage of the elevated structure provided by large structural basibionts. 'Hormathiidae' and Poliometra prolixa, a
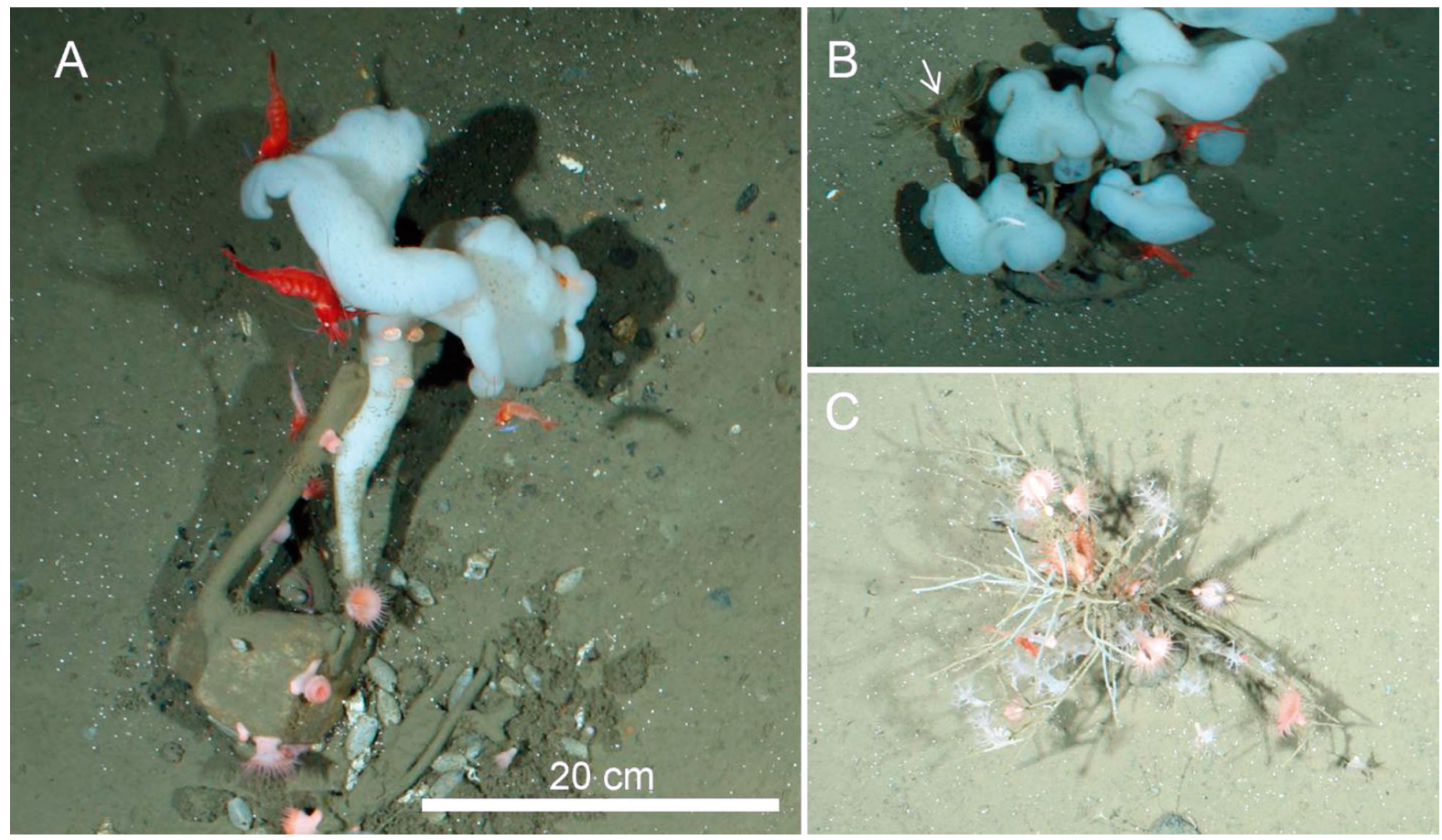

Fig. 8. (A) Crustaceans including Bythocaris cf. leucopis and 'amphipod' resting on Caulophacus arcticus; (B) Poliometra prolixa (white arrow) and B. cf. leucopis on C. arcticus; (C) 'Hormathiidae' as an epibiont on Cladorhiza cf. gelida 
comatulid crinoid, are suspension feeders (Bergmann et al. 2009). A number of species live on or are associated with large structural coral species in the deep sea (Cordes et al. 2008), and deep-sea suspension feeders climb on stones, sponges, or the spines of sea urchins to elevate themselves off the seafloor and expose themselves to better currents (Gutt \& Schickan 1998). 'Hormathiidae' is very likely elevating itself for suspension feeding by living atop $C$. cf. gelida, and it also inhabits stalks of the crinoid Bathycrinus carpenterii (Fig. S6B; M. Bergmann unpubl. data). Similar epibiotic relationships have been found for Antarctic fauna and are mostly likely commensal (Gutt \& Schickan 1998). Morphotypes that utilized large structural basibionts also co-occurred more often than expected by chance ('Hormathiidae' - B. cf. leucopis at Stns S3 and N5; Poliometra prolixa - B. cf. leucopis and Poliometra prolixa - 'amphipod' at Stn HG IV). It is not entirely clear what advantage $B$. cf. leucopis and the amphipod gain by resting on large sponges, although they may be protected from predators or gain some advantage in feeding.

Other pairs of species co-occurred more often than expected, although the reason is not so obvious. In the case of 'lobe-like sponge' (Fig. S2D) and 'pycnogonid' (Fig. S5C) at Stn S3, perhaps one is the prey of the other. For the pair Polymastia sp. (Fig. S2B) and 'thin white encrustment' (Fig. S3C) at Stn HG IV, we are unable to conjecture a reason.

\section{CONCLUSION}

Dropstones constitute island-like habitats for hardbottom fauna at high latitude. While the patterns observed in dropstone communities bear some resemblance to classical island systems, the mechanisms causing these patterns are not necessarily the same. Differences in primary productivity, habitat diversity, and physical disturbance are not satisfactory explanations for the distributions of dropstone fauna; rather, simple mechanisms such as hydrodynamics and larval dispersal offer parsimonious explanations. This study is to our knowledge the first time that positive non-random co-occurrence patterns have been shown for island-like fauna. An understanding of dropstone communities provides new insights for studies in other island-like habitats.

Acknowledgements. We thank the officers and crew of RV 'Polarstern' for their assistance at sea. Dorte Janussen (sponges; Senckenberg Museum of Natural History), Andrey Vedenin (crustaceans, echinoderms; P. P. Shirshov
Institute of Oceanology), Leen van Ofwegen (cnidarians; National Museum of Natural History), Estefania Rodriguez (cnidarians; American Museum of Natural History) kindly identified species from voucher specimens or photos. Nicholas Gotelli (University of Vermont) and Frances White (University of Oregon) provided statistical guidance. Comments from Michelle Wood and Alan Shanks (University of Oregon) and 4 anonymous reviewers improved earlier versions of the manuscript. This material is based upon work supported by the National Science Foundation Graduate Research Fellowship Program under Grant No. DGE0829517. M.B. was funded by the Helmholtz Alliance ROBEX (Robotic Exploration of Extreme Environments). This study contributes to the tasks of the Helmholtz-funded program FRAM (Frontiers in Arctic Marine Research) and has Eprint ID 37698 of the Alfred-Wegener-Institut Helmholtz-Zentrum für Polar und Meeresforschung, Germany.

\section{LITERATURE CITED}

Abele LG, Patton WK (1976) The size of coral heads and the community biology of associated decapod crustaceans. J Biogeogr 3:35-47

Anderson WB, Wait DA (2001) Subsidized island biogeography hypothesis: another new twist on an old theory. Ecol Lett 4:289-291

Beaulieu SE (2001) Colonization of habitat islands in the deep sea: recruitment to glass sponge stalks. Deep-Sea Res I 48:1121-1137

Bergmann M, Dannheim J, Bauerfeind E, Klages M (2009) Trophic relationships along a bathymetric gradient at the deep-sea observatory HAUSGARTEN. Deep-Sea Res I 56:408-424

> Bergmann M, Soltwedel T, Klages M (2011) The interannual variability of megafaunal assemblages in the Arctic deep sea: preliminary results from the HAUSGARTEN observatory $\left(79^{\circ} \mathrm{N}\right)$. Deep-Sea Res I 58:711-723

Bienhold C, Pop Ristova P, Wenzhöfer F, Dittmar T, Boetius A (2013) How deep-sea wood falls sustain chemosynthetic life. PLOS ONE 8:e53590

Borregaard MK, Matthews TJ, Whittaker RJ (2016) The general dynamic model: towards a unified theory of island biogeography? Glob Ecol Biogeogr 25:805-816

Clark MR, Rowden AA, Schlacher T, Williams A and others (2010) The ecology of seamounts: structure, function, and human impacts. Annu Rev Mar Sci 2:253-278

Connor EF, McCoy ED (1979) The statistics and biology of the species-area relationship. Am Nat 113:791-833

Connor E, Simberloff D (1979) The assembly of species communities: chance or competition? Ecology 60:1132-1140

Cordes EE, McGinley MP, Podowski EL, Becker EL, Lessard-Pilon SA, Viada ST, Fisher CR (2008) Coral communities of the deep Gulf of Mexico. Deep-Sea Res I 55: 777-787

> De Leo FC, Smith CR, Rowden AA, Bowden DA, Clark MR (2010) Submarine canyons: hotspots of benthic biomass and productivity in the deep sea. Proc R Soc B 277: 2783-2792

Diamond JM (1975) Assembly of island communities. In: Cody ML, Diamond JM (eds) Ecology and evolution of communities. Belknap Press of Harvard University Press, Cambridge, p 342-444

Entsminger G (2014) EcoSim Professional: null modeling software for ecologists, vers. 1. Acquired Intelligence, 
Kesey-Bear and Pinyon Publishing, Montrose, CO, USA

Gotelli NJ (2000) Null model analysis of species co-occurrence patterns. Ecology 81:2606-2621

> Gotelli NJ (2001) Research frontiers in null model analysis. Glob Ecol Biogeogr 10:337-343

Gotelli NJ, Graves GR (1996) Null models in ecology. Smithsonian Institution Press, Washington DC and London

Gotelli NJ, Ulrich W (2010) The empirical Bayes approach as a tool to identify non-random species associations. Oecologia 162:463-477

Grantham BA, Eckert GL, Shanks AL (2003) Dispersal potential of marine invertebrates in diverse habitats. Ecol Appl 13:S108-S116

Gutt J, Schickan T (1998) Epibiotic relationships in the Antarctic benthos. Antarct Sci 10:398-405

$>$ Hagen JO, Melvold K, Pinglot F, Dowdeswell JA (2003) On the net mass balance of the glaciers and ice caps in Svalbard, Norwegian Arctic. Arct Antarct Alp Res 35: 264-270

Hasemann C, Bergmann M, Kanzog C, Lochthofen N, Sauter E, Schewe I, Soltwedel T (2013) Effects of dropstone-induced habitat heterogeneity on Arctic deep-sea benthos with special reference to nematode communities. Mar Biol Res 9:229-245

Hétérier V, David B, De Ridder C, Rigaud T (2008) Ectosymbiosis is a critical factor in the local benthic biodiversity of the Antarctic deep sea. Mar Ecol Prog Ser 364:67-76

Jackson JBC (1986) Modes of dispersal of clonal benthic invertebrates: consequences for species' distributions and genetic structure of local populations. Bull Mar Sci 39:588-606

Kidd RBB, Huggett QJ, Huggett J (1981) Rock debris on abyssal plains in the northeast Atlantic - a comparison of epibenthic sledge hauls and photographic surveys Oceanol Acta 4:99-104

Kukli ski P (2009) Ecology of stone-encrusting organisms in the Greenland Sea - a review. Polar Res 28:222-237

> Lomolino MV (2000) A call for a new paradigm of island biogeography. Glob Ecol Biogeogr 9:1-6

> Lutz R, Kennish MA (1993) Ecology of deep-sea hydrothermal vents: a review. Rev Geophys 31:211-242

MacArthur RH, Wilson EO (1967) The theory of island biogeography. Princeton University Press, Princeton, NJ

> MacDonald IR, Bluhm BA, Iken K, Gagaev S, Strong S (2010) Benthic macrofauna and megafauna assemblages in the Arctic deep-sea Canada Basin. Deep-Sea Res II 57: 136-152

- Marshall DJ, Keough MJ (2003) Variation in the dispersal potential of non-feeding invertebrate larvae: the desperate larva hypothesis and larval size. Mar Ecol Prog Ser 255:145-153

- Marshall DJ, Keough MJ (2004) Variable effects of larval size on post-metamorphic performance in the field. Mar Ecol Prog Ser 279:73-80

- Meyer KS, Bergmann M, Soltwedel T (2013) Interannual variation in the epibenthic megafauna at the shallowest station of the HAUSGARTEN observatory (79 N, 6 E). Biogeosciences 10:3479-3492

- Meyer KS, Soltwedel T, Bergmann M (2014) High biodiversity on a deep-water reef in the eastern Fram Strait. PLOS ONE 9:e105424

> Mortensen PB, Hovland T, Fosså JH, Furevik DM (2001) Distribution, abundance and size of Lophelia pertusa coral reefs in mid-Norway in relation to seabed characteristics. J Mar Biol Assoc UK 81:581-597
Mullineaux LS (1987) Organisms living on manganese nodules and crusts: distribution and abundance at three north Pacific sites. Deep-Sea Res 34:165-184

Mullineaux LS (1988) The role of settlement in structuring a hard-substratum community in the deep sea. J Exp Mar Biol Ecol 120:247-261

Oschmann W (1990) Dropstones-rocky mini-islands in high-latitude pelagic soft-substrate environments. Senckenb Marit 21:55-75

Paradis E, Claude J, Strimmer K (2004) APE: analyses of phylogenetics and evolution in R language. Bioinformatics 20:289-290

R Development Core Team (2013) R: a language and environment for statistical computing. R Foundation for Statistical Computing, Vienna

Rusterholz KA, Howe RW (1979) Species-area relations of birds on small islands in a Minnesota lake. Evolution 33: 468-477

Schoener A, Schoener TW (1981) The dynamics of the species-area relation in marine fouling systems: 1 . biological correlates of change in the species-area slope. Am Nat 118:339-360

Schulz M, Bergmann M, von Juterzenka K, Soltwedel T (2010) Colonisation of hard substrata along a channel system in the deep Greenland Sea. Polar Biol 33: 1359-1369

Sebens KP (1986) Spatial relationships among encrusting marine organisms in the New England subtidal zone. Ecol Monogr 56:73-96

Shanks AL, Grantham BA, Carr MH (2003) Propagule dispersal and the size and spacing of marine reserves. Ecol Appl 13:S159-S169

Sibuet M, Olu K (1998) Biogeography, biodiversity, and fluid dependence of deep-sea cold-seep communities at active and passive margins. Deep-Sea Res II 45: $517-567$

Smith CR, Baco A (2003) Ecology of whale falls at the deepsea floor. Oceanogr Mar Biol Annu Rev 41:311-354

> Soltwedel T, Bauerfeind E, Bergmann M, Budaeva N and others (2005) HAUSGARTEN: Multidisciplinary investigations at a deep-sea, long-term observatory in the Arctic Ocean. Oceanography (Wash DC) 18:46-61

Soltwedel T, Bauerfeind E, Bergmann M, Bracher A and others (2016) Natural variability or anthropogenicallyinduced variation? Insights from 15 years of multidisciplinary observations at the arctic marine LTER site HAUSGARTEN. Ecol Indic 65:89-102

Sousa WP (1979) Disturbance in marine intertidal boulder fields: the nonequilibrium maintenance of species diversity. Ecology 60:1225-1239

Taylor J, Krumpen T, Soltwedel T, Gutt J, Bergmann M (2016) Regional- and local-scale variations in benthic megafaunal composition at the Arctic deep-sea observatory HAUSGARTEN. Deep-Sea Res I 108:58-72

Tjørve E (2010) How to resolve the SLOSS debate: lessons from species-diversity models. J Theor Biol 264:604-612

Ulrich W (2006) Nestedness - a FORTRAN program for calculating ecological temperatures. www.uni.torun.pl/ $\sim$ ulrichw

Ulrich W (2008) Pairs - a FORTRAN program for studying pair-wise species associations in ecological matrices. www.uni.torun.pl/ ulrichw

Ulrich W, Gotelli NJ (2007) Null model analysis of species nestedness patterns. Ecology 88:1824-1831

Vogel S (1996) Life in moving fluids: the physical biology of 
flow. Princeton University Press, Princeton, NJ

Wentworth CK (1922) A scale of grade and class terms for clastic sediments. J Geol 30:377-392

Whittaker RJ, Fernandez-Palacios JM (2007) Island biogeography: ecology, evolution, and conservation. Oxford University Press, Oxford

Whittaker RJ, Triantis KA, Ladle RJ (2008) A general dynamic theory of oceanic island biogeography. J Biogeogr 35:977-994

Young C (1989) Larval depletion by ascidians has little effect

Editorial responsibility: Antony Underwood,

Sydney, New South Wales, Australia on settlement of epifauna. Mar Biol 102:481-489

Young CM (2009) Communities on deep-sea hard bottoms. In: Wahl $\mathrm{M}$ (ed) Marine hard bottom communities. Springer-Verlag, Berlin, p 39-60

Young CM, Cameron JL (1989) Differential predation by barnacles upon larvae of two bryozoans: spatial effects at small scales. J Exp Mar Biol Ecol 128:283-294

Young CM, Gotelli NJ (1988) Larval predation by barnacles: effects on patch colonization in a shallow subtidal community. Ecology 69:624-634

Submitted: April 1, 2016; Accepted: June 30, 2016

Proofs received from author(s): August 21, 2016 